Dinamika Kesehatan Jurnal Kebidanan dan Keperawatan Vol 11 No. 1 Juli 2020 ( ISSN: 2086-3454 EISSN: 2549-4058)

url: http://ojs.dinamikakesehatan.unism.ac.id DOI : https://doi.org/10.33859/dksm.v11i1

Peran Dosen Keperawatan Sebagai Role Model Pendidikan Kesehatan Berbasis Karakater

\title{
Peran Dosen Keperawatan Sebagai Role Model Pendidikan Kesehatan Berbasis Karakater
}

\section{Agustinus Hermino}

Universitas Sari Mulia, Banjarmasin, Kalimantan Selatan

agustinushermino@unism.ac.id, agustinus_hermino@yahoo.com

DOI: $\underline{10.33859 / \mathrm{dksm} . v 11 \mathrm{i1} .623}$

\begin{abstract}
Abstrak
Latar belakang: Pendidikan kesehatan yang bertujuan melahirkan insan cerdas dan berkarakter kuat. Dengan pendidikan kesehatan berbasis karakter yang diterapkan secara sistematis dan berkelanjutan, seorang mahasiswa keperawatan akan menjadi memiliki pemahaman yang baik tentang pentingnya hidup sehat dan berkehidupan sehat. Hal ini penting untuk mempersiapkan mahasiswa keperawatan menjadi insan yang sehat secara jasmani maupun rohani, dan menjadi insan yang cerdas dalam menghadapi segala macam tantangan kehidupan, termasuk tantangan untuk berhasil secara akademis.
\end{abstract}

Tujuan: memberikan pemahaman kepada Dosen Keperawatan dan orangtua sebagai pendidik di perguruan tinggi maupun di rumah dalam menumbuh kembangkan aspek-aspek hidup sehat dan berkehidupan sehat dalam peibatan tiga aspek, yaitu aspek pengetahuan (cognitive), perasaan (feeling), dan tindakan (action) yang pada akhirnya akan menjadi sebuah pembiasaan positif untuk hidup bersih dan sehat, baik untuk dirinya sendiri maupun lingkungannya.

Metode: Penulisan ilmiah ini dilakukan dengan melakukan analisa akademik dari aspek berbagai sumber rujukan relevan sehingga menemukan makna teoritis baru dalam rangka menjawab tantangan yang terjadi di masyarakat.

Hasil: Pendidikan kesehatan berbasis karakter dapat diajarkan melalui metode internalisasi dengan mengedepankan pada peneladanan, pembiasaan, penegakan peraturan, dan pemotivasian. Dengan demikian maka pendidikan kesehatan berbasis karakter dapat dilakukan secara intrakurikuler maupun ekstrakurikuler. Intrakurikuler terintegrasi ke dalam matapelajaran, sedangkan ekstrakurikuler dilakukan di luar jam pelajaran, dimana kesemuanya dapat dilakukan melalui keteladanan, penanaman kedisiplinan, pembiasaan, penciptaan suasana kondusif dan integrasi-internalisasi. Disamping itu, kolaborasi komunikasi antara orangtua dan dosen kepada anak atau mahasiswa akan membawa mahasiswa pada tumbuh kembangnya karakter yang baik dan kuat akan pentingnya hidup sehat dan berkehidupan sehat yang akan menunjang pencapaian masa depan yang baik.

Kata kunci: pendidikan kesehatan, karakter, hidup sehat 


\section{The Role of Nursing Lecturers as Character-Based Role Models for Health Education}

\section{Abtract}

Background: Health education aimed at giving a meaning to intelligent people and strong characters. With character-based health education that is applied systematically and sustainably, $a$ child will have a good understanding of the importance of healthy living and healthy living. This is important to prepare children to be healthy individuals physically and spiritually, and to be intelligent people in facing all kinds of life's challenges, including challenges to succeed academically.

Purpose: Character-based health education has the aim to provide understanding to lecturers and parents as educators at the university and at home in developing aspects of healthy living and healthy living in engaging three aspects, namely aspects of knowledge or cognitive, feeling, and actions that will eventually become a positive habit to live clean and healthy, both for themselves and the environment.

Method: This scientific paper is carried out by conducting academic analysis from various aspects of relevant reference sources so as to find new theoretical meaning in order to answer the challenges that occur in society.

Results: Character-based health education can be taught through internalization methods by prioritizing modeling, habituation, rule enforcement, and motivation. Thus, character-based health education can be done intracuricularly or extracurricularly. Intrakuricular is integrated into the subjects, while extracurriculars are done outside of class hours, all of which can be done through example, instilling discipline, habituation, creating a conducive atmosphere and integrationinternalization. In addition, communication collaboration between parents and lecturers to children or students will bring students to the development of good and strong character of the importance of healthy living and healthy living that will support the achievement of a good future.

Keywords: health education, character, healthy life

\section{Pendahuluan}

Karakter adalah cara berpikir dan berperilaku yang menjadi ciri khas tiap individu untuk hidup dan bekerjasama, baik dalam lingkup keluarga, masyarakat, bangsa dan negara. Individu yang berkarakter baik adalah individu yang bisa membuat keputusan dan siap mempertanggungjawabkan tiap akibat dari keputusan yang ia buat.

Pembentukan karakter merupakan salah satu tujuan pendidikan nasional. Pasal I UU Sisdiknas No. 20 tahun 2003 menyatakan bahwa di antara tujuan pendidikan nasional adalah mengembangkan potensi peserta didik untuk memiliki kecerdasan, kepribadian dan akhlak mulia.

Amanah UU Sisdiknas tahun 2003 itu bermaksud agar pendidikan tidak hanya membentuk insan Indonesia yang cerdas, namun juga berkepribadian atau berkarakter, sehingga nantinya akan lahir generasi bangsa yang tumbuh berkembang dengan karakter yang bernafas nilai-nilai luhur bangsa serta agama. Untuk membentuk insan yang cerdas tersebut maka diperlukan tubuh yang sehat, jasmani yang sehat, serta pemikiran yang 
sehat, sehingga tercipta aura positif dalam pemikiran dan perilaku yang ada.

Pendidikan kesehatan yang bertujuan melahirkan insan cerdas dan berkarakter kuat tersebut seperti dikemukakan oleh Martin Luther King dalam Slavin (2006: 121), yakni: health education to build intelligence plus character... that is the goal of true education (pendidikan kesehatan untuk kecerdasan yang berkarakter... adalah tujuan akhir pendidikan yang sebenarnya). Memahami pendidikan kesehatan yang berbasis karakter tidak terlepas dari pelibatan aspek pengetahuan (cognitive), perasaan (feeling), dan tindakan (action).

Dengan pendidikan kesehatan berbasis karakter yang diterapkan secara sistematis dan berkelanjutan, seorang anak akan menjadi cerdas emosinya. Kecerdasan emosi ini merupakan bekal penting dalam mempersiapkan anak menyongsong masa depan, karena seseorang akan lebih mudah dan berhasil menghadapi segala macam tantangan kehidupan, termasuk tantangan untuk berhasil secara akademis.

Dasar pendidikan kesehatan berbasis karakter ini, tentunya akan efektif bila diterapkan sejak usia kanak-kanak atau yang biasa disebut para ahli psikologi sebagai usia emas (golden age), karena usia ini terbukti sangat menentukan kemampuan anak dalam mengembangkan potensinya. Hasil penelitian yang dilakukan oleh Upright (2002) menunjukkan bahwa sekitar 50\% variabilitas kecerdasan orang dewasa sudah terjadi ketika anak berusia 4 tahun. Peningkatan 30\% berikutnya terjadi pada usia 8 tahun, dan $20 \%$ sisanya pada pertengahan atau akhir dasawarsa kedua. Dari sini, sudah sepatutnya pendidikan karakter dimulai dari dalam keluarga, yang merupakan lingkungan pertama bagi pertumbuhan karakter anak.

Namun bagi sebagian keluarga, barangkali proses pendidikan kesehatan berbasis karakter yang sistematis di atas sangat sulit, terutama bagi sebagian orangtua yang terjebak pada rutinitas yang padat. Karena itu, seyogyanya pendidikan kesehatan berbasis karakter juga perlu diberikan saat anak-anak masuk dalam lingkungan perguruan tinggi, terutama sejak play group dan taman kanakkanak. Di sinilah khususnya peran dosen keperawatan, yang dalam filosofi Jawa disebut dosen atau diistilahkan sebagai digugu lan ditiru, dipertaruhkan. Karena dosen keperawatan adalah ujung tombak di kelas, yang berhadapan langsung dengan peserta didik.

Hal itu sesuai dengan pendapat Daniel Goleman dalam Seefeldt (2005) tentang keberhasilan seseorang di masyarakat, ternyata 80 persen dipengaruhi oleh kecerdasan emosi yang diawali dengan kesadaran akan pentingnya kesehatan, dan hanya 20 persen ditentukan oleh kecerdasan otak (IQ). Anakanak yang mempunyai masalah dalam kecerdasan emosinya, akan mengalami kesulitan belajar, bergaul dan tidak dapat mengontrol emosinya. Anak-anak yang 
Dinamika Kesehatan Jurnal Kebidanan dan Keperawatan Vol 11 No. 1 Juli 2020 ( ISSN: 2086-3454 EISSN: 2549-4058)

url: http://ojs.dinamikakesehatan.unism.ac.id DOI : https://doi.org/10.33859/dksm.v11i1

Peran Dosen Keperawatan Sebagai Role Model Pendidikan Kesehatan Berbasis Karakater

bermasalah ini sudah dapat dilihat sejak usia pra-perguruan tinggi, dan kalau tidak ditangani akan terbawa sampai usia dewasa. Sebaliknya para remaja yang berkarakter akan terhindar dari masalah-masalah umum yang dihadapi oleh remaja seperti kenakalan, tawuran, narkoba, miras, perilaku seks bebas, dan perbuatan atau perilaku yang menyimpang dari aspek kesehatan secara umum.

Beberapa negara yang telah menerapkan pendidikan kesehatan berbasis karakter sejak pendidikan dasar di antaranya adalah; Amerika Serikat, Hongkong, Jepang, Cina, Singapura dan Korea. Hasil penelitian di negara-negara ini menyatakan bahwa implementasi pendidikan kesehatan berbasis karakter yang tersusun secara sistematis berdampak positif pada pencapaian akademis Przybylska, et al (2014).

\section{Pengertian Pendidikan Kesehatan Berbasis}

\section{Karakter}

Ditinjau dari sudut etimologi, kata "karakter" atau dalam bahasa Inggris disebut "character" berasal dari kata Yunani "charassein", dalam Webster's New World Dictionary of the American Language, "karakter" diartikan sebagai "pola perilaku moral individu." Oleh karena itu, pendidikan kesehatan berbasis karakter dapat didefinisikan sebagai upaya membentuk pola perilaku moral individu untuk hidup secara sehat baik dari aspek jasmani maupun rohani melalui proses yang berkesinambungan. Oleh karena itu pendidikan kesehatan berbasis karakter yang paling utama sejatinya diberikan kepada seorang anak, sejak usia dini, dalam institusi pendidikan yang paling kecil namun berperan paling penting, yaitu keluarga. Dalam lingkup keluarga, seorang anak akan diberikan pemahaman akan makna kesehatan dan dapat dibentuk karakter atau pola perilaku moralnya oleh orangtua yang terdiri dari ayah dan ibu.

Selain keluarga, terdapat institusi pendidikan yang bisa dilibatkan oleh orangtua untuk menanamkan pemahaman akan pentingnya kesehatan dalam penumbuh kembangan melalui karakter yang baik dalam diri anak-anak mereka. Institusi pendidikan yang dimaksud adalah perguruan tinggi. Sebagai institusi pendidikan formal, perguruan tinggi mulai dari jenjang pendidikan awal hingga jenjang pendidikan tinggi berkewajiban untuk membentuk karakter setiap peserta didiknya. Hal ini dikarenakan perguruan tinggi merupakan mitra dari orangtua dalam mendidik anak-anaknya untuk membentuk pola kepribadian, perilaku, sifat, tabiat, dan watak.

Oleh karena itu pendidikan kesehatan berbasis karakter adalah usaha aktif untuk membekali pengetahuan tentang kesehatan, menanamkan kecintaan akan pentingnya hidup sehat serta membentuk kebiasaan hidup sehat sesuai dengan nilai, norma, budaya, dan agama yang dianut, serta mengedepankan serangkaian sikap (attitudes), perilaku (behaviors), motivasi (motivations) dan 
Dinamika Kesehatan Jurnal Kebidanan dan Keperawatan Vol 11 No. 1 Juli 2020 ( ISSN: 2086-3454 EISSN: 2549-4058)

url: http://ojs.dinamikakesehatan.unism.ac.id DOI : https://doi.org/10.33859/dksm.v11i1

Peran Dosen Keperawatan Sebagai Role Model Pendidikan Kesehatan Berbasis Karakater

keterampilan (skills) akan pemahaman pentingnya hidup sehat. Dengan adanya pemahaman yang baik ini maka pendidikan kesehatan berbasis karakter dapat membentuk kepribadian yang menjadi ciri hidup sehat dan berperilaku sehat sesuai dengan karakteristik, gaya atau sifat khas dari diri seseorang yang bersumber dari bentukan-bentukan yang diterima dari lingkungan (acquired) dan jiwa bawaan seseorang sejak lahir (iborn).

\section{Konsep Pendidikan Kesehatan Berbasis}

\section{Karakter}

Pendidikan kesehatan berbasis karakter adalah pendidikan yang memberikan pemahaman akan pentingnya hidup sehat yang dilandaskan pada kedalaman budi pekerti, yaitu yang melibatkan aspek pengetahuan (cognitive), perasaan (feeling), dan tindakan (action) untuk dapat secara terus menerus menerapkan dan mempraktekkan secara sadar tentang pentingnya pola hidup sehat.

Membangun karakter dari pintu pendidikan kesehatan perlu dilakukan secara komprehensif, tidak hanya melalui pendidikan formal, namun juga melalui pendidikan nonformal. Berkenaan dengan hal ini maka memerlukan 11 prinsip agar pendidikan kesehatan berbasis karakter dapat berjalan efektif, yaitu seperti: 1) pengembangan makna dasar dari hidup sehat dan kehidupan yang sehat sebagai fondasi; 2) pendefinisian karakter secara komprehensif yang mencakup pikiran, perasaan dan perilaku; 3) menggunakan pendekatan pola hidup sehat yang komprehensif disengaja dan pro aktif; 4) menciptakan komunitas perguruan tinggi yang penuh perhatian akan pentingnya hidup sehat; 5) memberi mahasiswa kesempatan untuk melakukan tindakan nyata sebagai aplikasi dari pola hidup sehat; 6) membuat kurikulum akademik bidang kesehatan yang aplikatif; 7) menumbuh kembangkan motivasi mahasiswa untuk dapat mempraktekkan pola hidu sehat; 8) melibatkan staf perguruan tinggi untuk proses aplikasi pelaksanaan pola hidup sehat dilingkungan perguruan tinggi; 9) menumbuhkan kebersamaan pola hidup sehat; 10) melibatkan keluarga dan anggota masyarakat sebagai mitra; 11) melakukan evaluasi karakter perguruan tinggi, fungsi staf perguruan tinggi sebagai pendidik karakter dan sejauh mana mahasiswa memanifestasikan karakter dengan baik.

Dengan adanya pendidikan kesehatan berbasis karakter yang diterapkan secara sistematis dan berkelanjutan, maka seorang anak akan menjadi cerdas emosinya (Putra, et al (2020). Kecerdasan emosi ini akan menjadi bekal penting dalam mempersiapkan anak menyongsong masa depan, karena seseorang akan lebih mudah dan berhasil menghadapi segala macam tantangan kehidupan, termasuk tantangan untuk berhasil secara akademis .

Pendidikan kesehatan berbasis karakter telah menjadi perhatian berbagai negara dalam rangka mempersiapkan generasi yang berkualitas, bukan hanya untuk kepentingan individu warga negara, tetapi juga untuk warga 
masyarakat secara keseluruhan. Pendidikan kesehatan berbasis karakter dapat diartikan sebagai "the deliberate us of all dimensions of school life to foster optimal character development" atau dapat diartikan sebagai sebuah upaya kita secara sengaja dari seluruh dimensi kehidupan di perguruan tinggi untuk membantu pembentukan karakter secara optimal.

Tujuan pendidikan kesehatan berbasis karakter adalah mengajarkan nilai-nilai kebermaknaan aspek kesehatan secara umum untuk kehidupan sehari-hari dengan mengedepankan nilai-nilai budaya lokal, aturan pemerintah, serta norma secara luas yang dapat diterima sebagai landasan perilaku yang baik dan bertanggung jawab. Keseluruhan makna tersebut juga digambarkan sebagai perilaku moral. Bila makna tersebut dapat diimplementasikan dengan baik dan terukur maka faktor kesehatan di Indonesia dapat berkontribusi nyata dalam memperbaiki mutu sumber daya manusia dan berkontribusi pula memperkuat sistem pendidikan yang ada, antara lain adanya generasi muda yang sehatg secara jasmani maupun rohani.

Berkenaan dengan hal di atas maka strategi pembelajaran yang berkenaan dengan: (a) moral knowing akan lebih mengedepankan pada pembelajaran berbasis inquiry yang berfokus pada sense of emphaty terhadap kondisi yang sedang terjadi dilingkungan sekitar; (b) moral loving akan lebih mengedepankan pada terjadinya pola interaksi dan komunikasi secara seimbang di antara mahamahasiswa dengan mahamahasiswa, maupun mahamahasiswa dengan dosen; dan (c) moral doing akan lebih banyak menggunakan pendekatan individual melalui pendampingan pemanfaatan potensi dan peluang yang sesuai dengan kondisi lingkungan mahamahasiswa. Ketiga strategi pembelajaran tersebut dirancang secara sistematis agar para mahamahasiswa dan dosen dapat memanfaatkan segenap nilai-nilai dan moral yang sesuai dengan potensi dan peluang yang tersedia di lingkungannya serta dapat mulai didorong tumbuhnya kesadaran akan pentingnya hidup sehat dan berkehidupan yang sehat pula.

Dengan demikian, hasil pembelajarannya ialah terbentuknya kebiasaan berpikir, bertindak, dan berperilaku secara sehat dalam arti peserta didik memiliki pengetahuan, kemauan dan keterampilan dalam berbuat kebaikan yang mebgedepankan pada kesadaran akan pentingnya hidup sehat secara lahiriah maupun batiniah. Melalui pemahaman yang komprehensif ini diharapkan dapat menyiapkan pola-pola manajemen pembelajaran pendidikan kesehatan berbasis karakter yang dapat menghasilkan anak didik yang memiliki karakter yang kuat dalam arti memiliki ketangguhan dalam keilmuan, keimanan, dan perilaku shaleh, baik secara pribadi maupun sosial.

Sejalan dengan pemahaman di atas, maka dari hasil pembelajaran kepada 
mahamahasiswa keperawatan tersebut dapat terbentuk empat ciri dasar dalam pendidikan kesehatan berabasis karakter, yaitu: pertama, keteraturan interior, di mana setiap tindakan diukur berdasar hierarki nilai. Nilai menjadi pedoman normatif setiap tindakan; kedua, koherensi yang memberi keberanian, membuat seseorang teguh pada prinsip, tidak mudah terombang-ambing pada situasi baru atau takut risiko; ketiga, otonomi di mana seseorang menginternalisasikan aturan dari luar sampai menjadi nilai-nilai bagi pribadi; dan keempat, keteguhan dan kesetiaan yang merupakan daya tahan seseorang guna mengingini apa yang dipandang baik, dan kesetiaan merupakan dasar bagi penghormatan atas komitmen yang dipilih. Dengan keempat makna tersebut maka para mahamahasiswa akan memiliki kesadaran untuk berbuat yang terbaik atau unggul, dan mereka juga diharapkan mampu bertindak sesuai potensi dan kesadarannya tersebut. Selain itu makna yang substansial dalam diri seorang mahamahasiswa yang berkarakter adalah senantiasa berusaha melakukan hal-hal yang terbaik terhadap Tuhan YME, dirinya, sesama manusia, lingkungan, bangsa dan negara serta dunia internasional pada umumnya dengan mengoptimalkan potensi (pengetahuan) dirinya dan disertai dengan kesadaran, emosi dan motivasi (perasaaannya).

Pada dasarnya, pendidikan kesehatan berbasis karakter memiliki esensi dan makna yang sama dengan pendidikan moral dan pendidikan akhlak, dimana tujuannya adalah membentuk pribadi anak agar menjadi manusia sehat secara jasmani dan rohani yang baik, dalam berkehidupan sebagai warga masyarakat dan warga negara yang baik dan sehat pula. Adapun kriteria yang baik bagi suatu masyarakat atau bangsa, secara umum adalah nilai-nilai sosial tertentu, yang banyak dipengaruhi oleh budaya masyarakat dan bangsanya.

Oleh karena itu, hakikat pendidikan kesehatan berbasis karakter dalam konteks pendidikan keperwatan di Indonesia adalah pendidikan nilai, yakni pendidikan nilai-nilai menjadi manusia yang cerdas yang didasarkan pada kesehatan jasmani dan rohani, yang bersumber dari budaya bangsa Indonesia sendiri, dalam rangka membina kepribadian generasi muda. Adapun aspek penguatan karakter berpijak pada karakter dasar manusia, yang bersumber dari nilai moral universal (bersifat absolut) yang bersumber dari agama yang juga disebut sebagai the golden rule. Dengan demikian maka pendidikan kesehatan berbasis karakter dapat memiliki tujuan yang pasti, apabila berpijak dari nilainilai karakter dasar tersebut, seperti cinta kepada Tuhan dan ciptaannya (alam dengan isinya), tanggung jawab, jujur, hormat dan santun, kasih sayang, peduli, dan kerja sama, percaya diri, kreatif, kerja keras, dan pantang menyerah, keadilan dan kepemimpinan, baik dan rendah hati, toleransi, cinta damai, dan cinta persatuan. 


\section{Fokus Pendidikan Kesehatan Berbasis}

\section{Karakter}

Terdapat tiga fokus pendidikan kesehatan berbasis karakter di era globalisasi saat ini yang perlu dimaknai dengan baik, yaitu: pertama, pendidikan kesehatan yang memusatkan diri pada pengajaran (teaching values), dimana aspek pembelajaran mengedepankan pada penanaman nilai-nilai akan pentingnya kesehatan secara akademik maupun pengimplementasian hidup sehat dalam praktik sehari-hari mulai dari sehat untuk diri sendiri, sehat untuk sesama, sehat untuk lingkungan dan sehat untuk hidup bersama di masyarakat yang lebih luas. Kedua, pendidikan kesehatan yang memusatkan diri pada klarifikasi nilai (value clarification), dimana aspek penjelasan dosen keperawatan akan menjadi sangat penting karena harus memberikan penjelasan terhadap aspek-aspek yang layak dan tidak layak, tepat atau tidak tepat. Proses ini merupakan pembelajaran berbasis pengalaman (learning experience) sehingga pengalaman baik dan/atau pembelajaran baik dari para dosen akan sangat berguna dalam menjelaskan kepada para mahamahasiswanya. Ketiga, pendidikan kesehatan yang mempergunakan pendekatan pertumbuhan moral (character development), dimana kolaborasi antara peran dosen dan orangtua menjadi sangat penting karena komunikasi antara keduanya akan sangat membantu bagi tumbuh kembangnnya kesadaran akan pentingnya hidup secara sehat dan berkehidupan secara sehat baik itu ditataran rumah maupun perguruan tinggi. Kolaborasi komunikasi dan kolaborasi perhatian antara dosen dan orangtua kepada mahamahasiswa akan membuat jiwa anak tumbuh dalam perhatian yang positif dan sehat.

Hal ini pula sejalan dengan yang dikemukakan dalam penelitian oleh Putra, et al (2020); Cavel (2010) bahwa pemahaman pentingnya hidup sehat dan berkehidupan secara sehat perlu ditanamkan sebagai nilainilai dari pendidikan karakter yang berpusat pada pengajaran yang mengutamakan isi nilainilai makna kesehatan secara harafiah dan aplikatif untuk dijelaskan dan dipelajari, sehingga dapat menjadi sebuah sekumpulan kualitas keutamaan moral yang diketahui dan dipahami oleh mahamahasiswa, dimana klarifikasi nilai lebih mengutamakan proses penalaran moral serta pemilihan nilai yang mesti dimiliki oleh mahamahasiswa.

Lebih lanjut pula Lie (2018) dan Lickona (1991) mengemukakan pula bahwa fokus penguatan tumbuh kembang karakter yang kuat bagi anak-anak adalah pada pertumbuhan karakter moral yang mengutamakan perilaku untuk merefleksikan penerimaan nilai serta menekankan unsur motivasi, serta aspek-aspek kepribadian yang relatif stabil yang akan mengarahkan tindakan individu. Fokus pertama mengutamakan pengetahuan dan pengertian (intelectual), 
fokus kedua, mengutamakan perilaku (conduct), namun tetap saja mereka memberikan prioritas pada pemahaman, serta proses pembentukan dan pemilihan nilai. Sedangkan fokus ketiga mengutamakan pertumbuhan motivasi internal dalam membentuk nilai selaras dengan tahap-tahap perkembangan moral individu.

Sejalan dengan hal tersebut diatas, Kaswardi (1993); Thurber \& Walton (2012) juga menegasan bahwa karakter atau akhlak diajarkan melalui metode internalisasi dengan mengedepankan pada peneladanan, pembiasaan, penegakan peraturan, dan pemotivasian. Dengan demikian maka pendidikan kesehatan berbasis karakter dapat dilakukan secara intrakurikuler maupun ekstrakurikuler. Intrakurikuler terintegrasi ke dalam matapelajaran, sedangkan ekstrakurikuler dilakukan di luar jam pelajaran, dimana kesemuanya dapat dilakukan melalui keteladanan, penanaman kedisiplinan, pembiasaan, penciptaan suasana kondusif dan integrasi-internalisasi.

\section{Pilar Pendidikan Kesehatan Berbasis} Karakter Bidang Keperawatan.

Pendidikan kesehatan berbasis karakter yang utuh dan menyeluruh menawarkan beberapa alternatif pengembangan keutamaan untuk membentuk pribadi yang sehat baik jasmani maupun rohani serta memiliki karakter individu menjadi pribadi berkeutamaan. Pilihan prioritas keutamaan tersebut didasarkan pada tiga matra, yaitu matra individual, matra sosial, dan matra moral. Pertama, matra individual. Pada matra ini mengedepankan akan pentingnya pemahaman hidup sehat dan berkehidupan sehat berdasarkan hal-hal yang telah diinformasikan oleh orangtua di rumah maupun dosen di perguruan tinggi. Pemahaman individu ini akan menjadi sebuah pembiasaan yang baik dimana masing-masing anak akan dapat menjalankan pola hidup sehat secara mandiri. Kedua, matra sosisl. Matra ini dapat berjalan dengan baik apabila matra individual telah berjalan dengan sebagaimana mestinya, dimana pembiasaan Pola Hidup Bersih dan Sehat (PHBS) yang telah rutin dilakukan secara mandiri akan berjalan terus dilingkungan sosial sehingga dapat menjadi embrio untuk pembiasaan hidup sehat dan berkehidupan yang sehat secara komunal. Ketiga, matra moral. Dengan berjalannya kedua matra sebelumnya maka selanjutnya akan menjadi gerakan moral untuk hidup sehat dan berkehidupan sehat. Matra moral mengedepankan keutamaan pada: 1) penghargaan terhadap kesehatan jasmani dan rohani; 2) pemghormatan akan pembiasaan baik dan contoh baik; 3) transendental dan keunggulan akademik; 4) penguasaan diri dan empathy; 5) keberanian dan tanggung jawab; 6) terampil dan demokratis; 7) menghargai perbedaan dan kearifan lokal; dan 8) integritas moral.

Dalam upaya pengimplementasian ketiga matra sebagaimana dijelaskan 
Dinamika Kesehatan Jurnal Kebidanan dan Keperawatan Vol 11 No. 1 Juli 2020 ( ISSN: 2086-3454 EISSN: 2549-4058)

url: http://ojs.dinamikakesehatan.unism.ac.id DOI : https://doi.org/10.33859/dksm.v11i1

Peran Dosen Keperawatan Sebagai Role Model Pendidikan Kesehatan Berbasis Karakater

sebelumnya, maka terdapat tiga desain implementasi pendidikan kesehatan berbasis karakter, yaitu pertama, desain pendidikan kesehatan dengan mengutamakan pembiasaan di kelas pada perguruan tinggi. Desain ini berbasis pada relasi dosen sebagai pendidik dan mahasiswa sebagai pembelajar di dalam kelas. Konteks pendidikan kesehatan adalah proses relasional komunitas kelas dalam konteks pembelajaran. Relasi dosenpembelajar bukan monolog, melainkan dialog dengan banyak arah sebab komunitas kelas terdiri dari dosen dan mahamahasiswa yang sama-sama berinteraksi dengan materi. Memberikan pemahaman dan pengertian akan keutamaan tentang hidup sehat dan berkehidupan sehat yang benar, termasuk di dalamnya pula adalah ranah noninstruksional, seperti manajemen kesehatan kelas, konsensus kelas terhadap hidup sehat, suasana belajar yang nyaman dan koridor berkehidupan yang sehat.

Kedua, desain pendidikan kesehatan dengan mengarusutaakan kultur perguruan tinggi. Desain ini membangun kultur perguruan tinggi berdasarkan nilai-nilai dan norma yang ditanamakan di perguruan tinggi yang mampu membentuk karakter anak didik dengan bantuan pranata sosial perguruan tinggi agar nilai tertentu terbentuk dan terbatinkan dalam diri mahasiswa. Untuk menanamkan nilai moral hidup sehat dan berkehidupan secara sehat tidak cukup hanya dengan memberikan pesan-pesan moral kepada mahamahasiswa. Pesan moral ini mesti diperkuat dengan penciptaan kultur pembiasaan melalui pembuatan tata peraturan perguruan tinggi yang tegas dan konsisten terhadap budaya untuk hidup bersih dan sehat.

Ketiga, desain pendidikan kesehatan dengan mengarusutamakan pembiasaan hidup sehat di komunitas. Dalam mendidik, komunitas perguruan tinggi tidak berjuang sendirian, namun masyarakat di luar lembaga pendidikan, seperti keluarga, masyarakat umum, dan negara, juga memiliki tanggung jawab moral untuk mengintegrasikan pembentukan pola hidup sehat dan berkehidupan yang sehat dengan basis karakter dalam konteks kehidupan mereka, sehingga makna karakter dapat berjelan dengan baik karena adanya dukungan komitmen dari masyarakat secara luas dan dilaksanakan secara simultan dan sinergis. Kesadaran komunal ini akan berdampak pada pembiasaan pola hidup sehat dalam segala aspek yang akan pula memperkuat kualitas sumber daya manusianya.

Anasir-anasir Strategis Pendidikan Kesehatan Berbasis Karakter Bidang Keperawatan

a) Peran Strategis Pendidik (Dosen Keperawatan) sebagai Role Model.

Dalam proses pendidikan kesehatan berbasis karakter, posisi dosen menempati posisi yang sangat sentral, karena melalui peran dosen proses transformasi nilai-nilai makna hidup sehat dan berkehidupan yang 
Dinamika Kesehatan Jurnal Kebidanan dan Keperawatan Vol 11 No. 1 Juli 2020 ( ISSN: 2086-3454 EISSN: 2549-4058)

url: http://ojs.dinamikakesehatan.unism.ac.id DOI : https://doi.org/10.33859/dksm.v11i1

Peran Dosen Keperawatan Sebagai Role Model Pendidikan Kesehatan Berbasis Karakater

sehat dapat dijelaskan dan dilakukan. Dengan demikian semestinya dalam proyeksi pendidikan kesehatan berbasis karakter tersebut penggagas utamanya harus berawal dari orangtua dalam kesehariannya di rumah, yang kemudian dikomunikasikan kepada dosen diperguruan tinggi sebagai upaya kolaborasi yang bersinergis. Dengan demikian maka para dosen perlu melakukan pembiasaan yang hidup yang sehat terlebih dahulu oleh dirinya sendiri melalui proses rutinitas sebagai karakter itu sendiri sebelum tampil untuk memposisikan diri sebagai pendidik kepada para mahasiswanya (Slavin, 2006). Dalam hal ini kompetensi yang harus dimiliki oleh seorang dosen adalah kemampuan untuk mengajar dan mengaarkan dengan maksimal yang diikuti oleh kompetensi kepribadian sebagai pendidik untuk mengantarkan peserta didik memiliki karakter akan pentingnya pola hidup bersih dan sehat dengan baik.

Realitas yang terjadi di dunia pendidikan pada masa sekarang adalah terjadinya krisis keteladanan di kalangan peserta didik, di mana dosen tidak mampu memosisikan diri sebagai significant person dan role model, terlebih lagi tidak mampu mengambil peran dan tanggung jawab sebagai orangtua ketika di perguruan tinggi. Akibatnya para mahasiswa mengadopsi atau mengambil tokoh-tokoh di luar dunia pendidikan, seperti para penyanyi, bintang film, dan tokoh-tokoh non- agama sebagai panutan dalam berprilaku. Maka wajar kemudian para mahasiswa sangat mudah terjerumus ke dalam perilaku dan karakter menyimpang dari norma-norma agama, sosial, dan budaya. Di saat orangtua dan dosen tidak mampu untuk memerankan diri sebagai figur panutan dalam melakukan proses transformasi karakter dan kepribadian, lalu para anak didik yang mendapatkan figur panutan yang salah, maka yang terjadi adalah split personality pada anak didik yang kemudian berujung pada terjadinya proses alienasi (keterasingan psikologis) pada mereka.

Bisa jadi fenomena hidup tanpa mengedepankan makna kesehatan, dekadensi moral yang terjadi di kalangan anak didik justru dipicu oleh ketidakmampuan orangtua dan dosen untuk mentransformasikan nilainilai berkehidupan sehat dalam basis tumbuh kembang karakter kepada anak didik. Dengan demikian apabila pendidikan kesehatan berbasis karakter menjadi arus utama dalam pendidikan nasional, yang semestinya dilakukan terlebih dahulu dengan mempersiapkan tenaga pengajar yang profesional memiliki kepribadian dan karakter yang baik, agar nantinya bisa menjadi figur panutan para mahasiswa atau anak didik. Tidak ketinggalan, mahamahasiswa yang suatu saat berminat untuk menjadi pendidik atau dosen harus mampu pula menciptakan dirinya sebagai calon dosen masa depan yang patut "digugu dan ditiru". Digugu artinya diikuti dan dipatuhi segala apa yang diucapkannya. Ditiru artinya dicontoh segala 
apa yang dilakukan dan apa yang diperbuat oleh dosen.

Dosen sebagai role model seharusnya memang menjadi sumber yang menginspirasi dan memotivasi peserta didik. Hal ini berarti bahwa ketika dosen sebagai profesi maka ia harus bertindak sebagai seorang profesional, artinya ketika dosen melaksanakan tugas, ia tidak hanya mengajar dikelas secara rutin, melainkan juga mendidik, membimbing, mengarahkan, melatih dan menilai Wannamaker (2013). Pendekatan keteladanan semua pihak inilah merupakan sarana yang memudahkan terbentuknya karakter anak-anak bangsa. Tanpa adanya role model, karakter tidak akan dapat dikembangkan dengan baik dan denganadanya peran model oleh dosen yang berkarakter, merupakan kunci utama di dalam pendidikan karakter (Wu, 2015; Upright, 2002).

\section{b) Perlunya Revolusi Pengajaran Pendidikan Kesehatan Berbasis Karakter}

Selain peran strategis dosen dalam proses pendidikan kesehatan berbasis karakter, maka juga perlu dilakukan revolusi dalam pengajaran. Sebagaimana yang ditegaskan Santoso (1981) dan Lickona (1991), bahwa model pembelajaran pendidikan yang mengedepankan nilai-nilai karakter untuk terciptanya berkehidupan yang sehat secara jasmani dan rohani diperlukan pengetahuan moral, agama dan karakter yang bergerak secara sinergis.

Dengan paradigma pembelajaran seperti ini, maka yang ditekankan oleh pendidik adalah penguasaan materi berdasarkan pembelajaran pengalaman hidup sehat dan berkehidupan sehat yang dipraktikkan langsung oleh dosen dengan kolaborasi bersama peran orangtua maka akan tersedia dan daya serap anak didik atau memorisasi praktis yang lebih dipentingkan. Praktik ini tergambar dengan jelas dalam model keseharian para dosen dan juga pembiasaan hidup sehat oleh anggota keluarga di dalam rumah yang akan dapat sebagai pemantik untuk tumbuh kembangnya hidup sehat bukan hanya dari aspek nasihat oleh dosen dan orangtua tetapi juga langsung masuk pada ranah praktik yang akan lebih mudah dipahami oleh para peserta didik atau mahasiswa.

Terciptanya model pembelajaran humanities ini maka akan sangat membantu mahasiswa untuk lebih menyerap dengan mudah apa yang sebaiknya dilakukan dan apa yang semestinya dihindari, serta kehumanitisan tersebut akan membawa mahasiswa memehami akan makna paradigma pendidikan kesehatan secara akademik dan praktis dengan basis karakter yang diarahkan pada kehendak dan motivasi, dan bukannya intelektualitas semata.

c) Model Evaluasi Pendidikan Kesehatan Berbasis Karakter 
Dinamika Kesehatan Jurnal Kebidanan dan Keperawatan Vol 11 No. 1 Juli 2020 ( ISSN: 2086-3454 EISSN: 2549-4058)

url: http://ojs.dinamikakesehatan.unism.ac.id DOI : https://doi.org/10.33859/dksm.v11i1

Peran Dosen Keperawatan Sebagai Role Model Pendidikan Kesehatan Berbasis Karakater

Adapun persoalan yang terkadang nampak atau muncul membingungkan ketika berbicara tentang karakter tersebut untuk dilakukan evaluasi, yaitu tentang cara dan tujuan evaluasi. Pendidikan karakter sering kali dianggap sebagai bidang yang sulit untuk diukur, dinilai dan dievaluasi karena harus mengukur atau menilai pengetahuan mahasiswa tentang makna hidup sehat dan berkehidupan yang sehat baik dari aspek akademis maupun praktik, dan hal ini terkadang memunculkan stigma melalui tes tertulis akan lebih mudah dibandingkan menilai perilaku mahasiswa. Ada persoalan serius berkaitan dengan cara-cara penilaian dalam pendidikan kesehatan berbasis karakter.

Masalah evaluasi sering dikaitkan dengan tujuan pendidikan kesehatan berbasis karakter itu sendiri. Apakah evaluasi mesti dikaitkan dengan kenaikan kelas, atau kelulusan, seperti yang selama ini dianjurkan pemerintah, di mana penilaian budi pekerti, perilaku, sikap, bisa menjadi alasan untuk tidak menaikkan atau meluluskan mahasiswa? Faktanya, kriteria penilaian yang sumir seperti ini sering kali hanya sekedar menjadi macam kertas, dan tidak terjadi di lapangan. Asal anak lulus ujian nasional, persoalan budi pekerti, moral, perilaku mahasiswa tampaknya masih bisa diabaikan.

Oleh karena itu dalam proses evaluasinya, pendidikan kesehatan berbasis karakter tidak saja berdiri sendiri dalam sebuah matapelajaran, akan tetapi penanaman nilainilai karakter dapat menjadi hidden curriculum dalam mata pelajaran tertentu yang basisnya adalah humanities. Selain itu proses penanaman nilai-nilai karakter dan sekaligus proses evaluasinya, juga tidak bisa hanya dimonopoli oleh pihak perguruan tinggi, akan tetapi melibatkan peran yang sifatnya sinergis antara orangtua di rumah, dan dosen di perguruan tinggi. Dalam hal ini dosen juga harus menjalin relasi yang baik dengan orangtua peserta didik. Hal ini seperti dikemukakan oleh Yarmohammadi, et al (2014) bahwa kolaborasi komunikasi yang terjalin baik antara orangtua mahasiswa dengan dosen di perguruan tinggi akan meningkatkan kepercayaan diri kepada anak atau mahasiswa untuk bisa belajar dengan baik, baik dari aspek akademis maupun perilaku kesehariannya.

\section{d) Dosen Sebagai Pembangun Citra Diri Positif Anak}

Banyak perilaku dosen yang dapat "membunuh" karakter anak, yaitu dengan membuat anak merasa rendah diri. Seorang dosen yang tidak pernah memberikan pujian atau kata-kata positif, kecuali cemoohan dan kata-kata negatif, akan membuat muridnya menjadi tidak percaya diri. Rasa tidak percaya diri yang telah terbentuk pada anak usia dini akan terbawa sampai dewasa. Peran dosen dalam membangun citra dosen yang positif pada anak sangat besar. 
Dinamika Kesehatan Jurnal Kebidanan dan Keperawatan Vol 11 No. 1 Juli 2020 ( ISSN: 2086-3454 EISSN: 2549-4058)

url: http://ojs.dinamikakesehatan.unism.ac.id DOI : https://doi.org/10.33859/dksm.v11i1

Peran Dosen Keperawatan Sebagai Role Model Pendidikan Kesehatan Berbasis Karakater

Menjadi dosen sebagai pendidik karakter tidak cukup hanya dengan membekali mereka dengan teori dan seperangkat kurikulum saja tetapi juga menyangkut bagaimana seorang dosen dapat menjadi idola bagi muridnya, sehingga setiap perkataan dan tingkah laku dosen akan ditiru oleh muridnya.

Seorang pendidik karakter yang berhasil adalah yang dapat mencelupkan dirinya secara menyeluruh (pikiran dan perasaan) ketika sedang mengajar, dapat membangun hubungan personal dengan murid-muridnya, mempunyai kemampuan komunikasi secara efektif, mampu mengelola emosinya dengan baik, serta mampu menghidupkan suasana. Mencelupkan diri secara total memang memerlukan sikap dedikasi dan kecintaan terhadap profesi yang sedang dijalaninya. Lickona mengatakan bahwa untuk membangun hubungan emosi dengan murid-muridnya, seorang dosen juga harus dapat menunjukkan bahwa dirinya juga adalah sebagai manusia yang mempunyai perasaan.

Seorang pendidik karakter yang baik adalah yang dapat memberikan inspirasi yang menggairahkan kepada muridnnya sehingga murid dapat jatuh cinta kepada kebajikan. Istilah "fall in love in goodness" atau jatuh cinta kepada kebajikan bisa dilakukan dengan cara penuh inspirasi sehingga anak-anak bergairah untuk selalu menjadi anak yang baik dan lebih baik lagi setiap saat. Karena cinta adalah sumber energi untuk kita senang dan gembira untuk melakukan kebajikan.

Kita semua para pendidik untuk terus menebarkan benih kebajikan walaupun kita tidak tahu bagaimana hasilnya nanti. Kemanapun kita pergi selalu menebarkan benih kebajikan dan tidak berfikir apakah benih yang kita tebar akan tumbuh dan juga tidak berniat menikmati buahnya atau berteduh dibawahnya. Di perguruan tinggi, dosen perlu mengajarkan pendidikan kesehatan berbasis karakter karena beberapa alasan, setidaknya meliputi: pertama, mahasiswa tidak selalu mendapatkan pendidikan kesehatan berbasis karakter di rumah. Sebenarnya pendidikan kesehatan berbasis karakter tersebut merupakan tugas orangtua secara awal di rumah, karena makna kesehatan pertama kali diajarkan dalam lingkungan keluarga. Orangtua yang ingin anaknya memiliki kesehatan yang baik dan kuat harus bersedia menyediakan waktu, energi, pikiran, dan materi untuk mewujudkannya. Namun, orangtua kadang sibuk bekerja dan tidak berkesempatan menghabiskan waktu bersama anak. Selain itu, anak yang berperguruan tinggi sampai sore dan memiliki kegiatan sesudah pulang perguruan tinggi, membuat mereka menghabiskan lebih banyak waktu dengan dosen daripada dengan orangtua.

Kedua, pendidikan kesehatan berbasis karakter dapat berjalan dengan baik apabila semua perangkat dalam keluarga dan perguruan tinggi membangun hubungan yang 
baik untuk tumbuh kembangnya karakter kuat dalam diri anak akan makna pentingnya hidup sehat dan berkehidupan sehat. Ketika mahasiswa berinteraksi dengan teman sebaya dan dosen, hubungan yang baik terjalin diantara mereka di ruang kelas. Hubungan ini tidak hanya sangat bermanfaat baik secara sosial mapun personal, namun juga meningkatkan manajemen pembelajaran yang efektif dalam suasanan yang nyaman.

Ketiga, pendidikan kesehatan berbasis karakter dapat menciptakan lingkungan perguruan tinggi yang positif. Dalam pembelajaran di kelas, kegiatan diskusi dan kegiatan lain membuat perguruan tinggi menjadi memiliki atmosfer positif. Mahasiswa berinteraksi dengan teman sebaya, dan hubungan mahasiswa-dosen semakin menguat. Kondisi ini memungkinkan dosen untuk berbagi pengalaman hidup. Keempat, pendidikan kesehatan berbasis karakter itu mudah dilakukan karena tidak harus menghabiskan waktu beberapa jam di kelas, namun dapat dilakukan dalam rutinitas hidup sehat mulai dari rumah sebagai aspek pembiasaan dan kemudian berlanjut di perguruan tinggi dalam berkehidupan bersama warga perguruan tinggi sehingga tercipta sebuah budaya dan pembiasaan yang baik akan pentingnya hidup sehat. Kelima, Pendidikan karakter dapat mengubah dunia. Mahasiswa di perguruan tinggi akan menjadi orang dewasa di masa depan. Mereka akan membentuk masyarakat. Memang penting bagi mereka untuk menjadi lulusan yang berpendidikan tinggi, namun yang lebih penting lagi adalah nilai bahwa mereka akan menjadi warga Negara yang hidup di dunia dalam keramahan, saling menghormati, bekerjasama dengan orang lain.

Dengan demikian maka dosen atau pendidik perlu: 1) menerapkan metode pembelajaran yang melibatkan partisipatif aktif mahasiswa; 2) menciptakan lingkungan belajar yang sehat dan kondusif; 3) memberikan pendidikan karakter secara eksplisit, sistematis, dan berkesinambungan dengan melibatkan aspek knowing the good, loving the good, and acting the good; dan 4) memperhatikan keunikan mahasiswa masingmasing dalam menggunakan metode pembelajaran. Hal ini seperti pula yang dikemukakan oleh Bustari (2005) bahwa dosen/pendidik perlu melatih dan membentuk karakter mahasiswa melalui pengulanganpengulangan sehingga terjadi internalisasi karakter secara konsisten.

Dalam proses pembelajaran inilah keterampilan intelektual dan motorik perlu dikembangkan, oleh karena itu dosen bertindak sebagai pelatih pada mahasiswanya. Dosen profesional dapat dilihat dari keterampilan mengajar (teaching skills) yang mereka miliki. Keterampilan mengajar yang dimiliki dosen dapat dilihat dari beberapa indikator antara lain: 1) dosen sebagai pembimbing dan fasilitator yang mampu menumbuhkan self learning pada diri 
Dinamika Kesehatan Jurnal Kebidanan dan Keperawatan Vol 11 No. 1 Juli 2020 ( ISSN: 2086-3454 EISSN: 2549-4058)

url: http://ojs.dinamikakesehatan.unism.ac.id DOI : https://doi.org/10.33859/dksm.v11i1

Peran Dosen Keperawatan Sebagai Role Model Pendidikan Kesehatan Berbasis Karakater

mahasiswa; 2) memiliki interaksi yang tinggi dengan seluruh mahasiswa di kelas; 3) memberikan contoh, pekerjaan yang menantang (challenging work); dengan tujuan yang jelas (clear objectives); 4) mengembangkan pembelajaran berbasis kegiatan dan tujuan; 5) melatih mahasiswa untuk bertanggung jawab terhadap pekerjaan mereka dan memiliki sense of ownership dan mandiri dalam pembelajaran; 6) mengembangkan pembelajaran individu; 7) melibatkan mahasiswa dalam pembelajaran maupun penyelesaian tugas-tugas melalui enquiry-based learning, misalnya dengan memberikan pertanyaan yang baik dan analitis; 8) menciptakan lingkungan pembelajaran yang positif dan kondusif; dan 9) memberikan motivasi dan kebanggaan yang tinggi.

Dengan memiliki keterampilan tersebut, maka peran dosen sangat penting dalam pembentukan karakter mahasiswa yang kuat dan positif. Dosen juga memiliki peran yang sangat vital dan fundamental dalam membimbing, mengarahkan, dan mendidik mahasiswa dalam proses pembelajaran (Rahman, 1998; Seefeldt, 2005). Karena peran mereka yang sangat penting itu, keberadaan dosen bahkan tak tergantikan oleh siapapun atau apapun sekalipun dengan teknologi canggih. Alat dan media pendidikan, sarana prasarana, multimedia dan teknologi hanyalah media atau alat yang hanya digunakan sebagai teachers' companion (sahabat - mitra dosen).
Oleh karena itu, ketika dosen harus membentuk mahasiswa agar berkarakter kuat, dosen itu sendiri sudah memilikinya, sehingga mahasiswa dapat meneladani perilaku, sikap, dan etika dosen yang dapat diamati dan dilihat mahasiswa dalam kehidupan sehari-hari. Dosen yang berkarakter adalah dosen yang memiliki nilai dan keyakinan yang dilandasi hakikat dan tujuan pendidikan serta digunakan sebagai kekuatan moral dalam menjalankan tugasnya sebagai pendidik. Oleh karena itu, dosen yang berkarakter kuat memiliki kemampuan mengajar, dan juga dapat menjadi teladan bagi mahasiswanya. Jadi dalam membentuk mahasiswa yang berkarakter kuat dan positif, dosen haruslah memiliki karakter yang kuat pula.

\section{A. Penutup}

Karakter merupakan kualitas atau kekuatan mental, moral, perilaku, sikap, dan kepribadian seseorang. Karakter merupakan kunci kesuksesan dalam kehidupan seseoran di masa depan. Pendidikan kesehatan berbasis karakter bidang keperwatan akan membentuk pribadi perawat yang cerdas dan berkarakter kuat, dan hal ini dapat diterapkan pada setiap matapelajaran perlu dikembangkan agar mahasiswa keperwatan menjadi manusia berkarakter.

Dosen keperawatan perlu mengembangkan nilai-nilai karakter dalam dirinya dan memilik peran penting dalam pembentukan karakter mahasiswa. Dosen 
keperawatan perlu pula memiliki karakter yang kuat dan positif untuk dapat membentuk mahasiswa keperawatan yang berkarakter. Mereka tidak hanya menjadi pendidik dan pengajar bagi mahasiswa, namun mereka mampu menjadi teladan bagi mahasiswa.

\section{DAFTAR PUSTAKA}

Bustari, M. 2005. Manajemen Peserta Didik. Yogyakarta: FIP UNY.

Cavell, T. A. 2010. Social Adjustment, Social Performance, and Social Skills: A Tri-Component Model of Social Competence. Journal of Clinical Child Psychology, 19(2), 111-122 http://dx.doi.org/10.1207/s15374424j ccp1902_2

Kaswardi, E.M. 1993. Pendidikan Nilai Memasuki Tahun 2000. Jakarta: Gramedia.

Lickona, T. 1991. Educating for Character. How Our Schools Can Teach Respect and Responsibility. Massachusetts: Allyn and Bacon, Inc.

Li, S. 2018. A Case Study of International Students' Social Adjustment, Friendship Development, and Physical Activity. Journal of International Students, 8(1), p 389408.http://dx.doi.org/10.5281/zenodo .1134317

Przybylska, D; Borzecki, A; Drop, B; Przbylski, P; Drop, K. 2014. Health Education as an Important Tool in the Healtcare System. Pol J Public Health. 2014; 124(3): 144-147. DOI: 10.2478/pjph-20140032.

Putra, I, E; Campbell-Obaid, M; Suwartono, C. 2020. Belief about Human Nature as Good versus Evil Influence Intergroup Attitudes and Values.
Peace and Conflict: Journal of Peace Psychology. ISSN: 10781919.http://dx.doi.org/10.1037/pac00 $\underline{00469}$.

Rahman, M.1998. Manajemen Kelas. Jakarta: Depdikbud.

Santoso, S. I. 1981. Pembinaan Watak Tugas Utama Pendidikan. Jakarta: Penerbit UI Press.

Seefeldt, C. 2005. Social Studies for the preschool/primary child (7th ed.). Upper Saddle River, NJ: Pearson.

Slavin, R.E. 2006. Educational Psycology: Theory and Pratice. Boston: Pearson Education, Inc.

Thurber \& Walton. 2012. Homesickness and Adjustment in University Students. Journal of American College Health, Vol.60, No.5. http://dx.doi.org/10.1080/07448481. $\underline{2012.673520}$

Upright, R. 2002. To tell a tale: The use of moral dilemmas to increase empathy in the elementary school child. Early Childhood Education Journal, 30, 1520.

Wannamaker, C. 2013. The Meaning and Significance of Social Adjustment. The Journal of Health and Physical Education, 10(1), p 12-54, http://dx.doi.org/10.1080/23267240. $\underline{1939.10622608}$

Wu, Hsiao-ping. 2015. International Student's Challenge and Adjustment to College. Hindawi Publishing Corporation Education Research International, http://dx.doi.org/10.1155/2015/2027 $\underline{53}$ 
Yarmohammadi, Amirsardari, Akbarzadeh,

Sepidarkish, \& Hashemian. 2014.

Evaluating the Relationship of

Anxiety, Stress and Depression with Sleep Quality of Students Residing at the Dormitories of Tehran University of Medical Sciences in 2013. World Journal of Medical Sciences, Vol. 11, No.4, p. 432-438. http://dx.doi.org/10.5829/idosi.wjms. 2014.11.4.84272. 